\title{
THE EFFECT OF ENTREPRENEURIAL EDUCATION AND PERSONALITY TO THE ENTREPRENEURIAL INTENTION THROUGH SELF-EFFICACY
}

Efa Wahyu Prastyaningtyas Nusantara PGRI University Kediri

efawahyu@unpkediri.ac.id

Budi Eko Soetjipto

Malang State University.

budi.eko.fe@um.ac.id

Ery Tri Djatmika Rudijanto Malang State University. ery.try.fe@um.ac.id

\begin{abstract}
Entrepreneurial education, entrepreneurial personality and selfefficacy are variables that vastly affect the entrepreneurial intention. It is an effort to nurture students' entrepreneurial intention of Teacher Training and Education Faculty at Nusantara PGRI University Kediri. This research aims to identify the indirect effect of entrepreneurial education and personality towards entrepreneurial intention through self-efficacy. The research sample is 151 students who received entrepreneurship course. The finding shows that entrepreneurial education and entrepreneurial personality affect the entrepreneurial intention through self-efficacy.
\end{abstract}

Keywords: Entrepreneurial Education; Entrepreneurial Personality; Self-Efficacy; Entrepreneurial Intention

Received November 2019 | Accepted December 2019 | Available online December 2019 |

| DOI: http://dx.doi.org (Editor only)

\section{INTRODUCTION}

Education is known as the main way to construct competitive human resource. Besides, excellent human resource is also needed when globalization make its entrance to Indonesia. The trade of goods and services among a country to another will be happened across each border geographically and territorially. Currently, one of the free market phenomenon occurs in the world is ASEAN Economic Community.

Having population of 253.609 .643 people, places Indonesia on the fourth rank of the densest country after China, India and United States (BPS, 2018). The unemployment number reached about 7,02 millions people (BPS, 2018). In other words, Indonesian needs to improve its human resource in better quality.

The highest numbers of unemployment were high school and vocational high school graduates (BPS, 2018). Hermawan (2003) stated that the main problem of graduates is individual independency. Besides, the work ethos especially in the scale of entrepreneurial mindset of vocational high school graduates is very low (Subijanto, 2012). The data from UKM of 2016 showed that Indonesia only have 1,56\% of entrepreneur. As a result it is needed to improve its entrepreneurship quantity. Similarly, Frinces (2010) suggested that nurturing entrepreneurship as early as possible could decrease the number of unemployment. 
The government improves the quality and the quantity of worker through vocational high school of which the effect is still trivial. The entrepreneurship then become a subject matter in every major or discipline in university. Nusantara PGRI University, Kediri, is one of those universities that devote the entrepreneurship education with the aim of increasing the number of entrepreneur in Indonesia or at least, it encourages its students to do business. Entrepreneurship education is an effort to internalize the entrepreneurship mentality through educational institute (Wibowo, 2011; Saroni, 2012; Izedonmi \& Okafor, 2010). Additionally, Tung (2011) stated that entrepreneurship education is a transmission process of knowledge and entrepreneur skills that help them to see and execute the business opportunity. There are five components of entrepreneurship education namely entrepreneurial Knowledge, Values and Motives, Social Interaction, Entrepreneurial Skill and Abilities (Tung, 2011).

The intention to carry out a business can be identified through entrepreneurial personality. Personality is a specific pattern in the way of thinking, feeling and behaving (Dorland, 2010; Anoraga, 2009). In addition, Alma (2007) said that decent personality will affect someone's intention to start a business. The features of personality are 'need of achievement and Locus of Control' (Kristiansen and Indarti, 2004; Linan, 2008; Sensen, 2013).

Bandura (1977) defined self efficacy as someone's trust his own ability to complete a task. A research also shows that self efficacy is connected to high entrepreneurial desire (Indarti \& Langeberg, 2004; Cruz, N.M., Escudero, Barahona \& Leitao (2009). There are four ways to achieve self efficacy, namely repetitive experience, learning through direct observation, social communication and judgment about the psychological state (Indarti \& Rostiani, 2008).

Entrepreneurial intention is people's main justification to be an entrepreneur. Tung (2011) said that the entrepreneurial intention can be understood as personal commitment to starting new business. Similarly, Lee \& Wong (2004) defined it as a way of thinking to encourage a person to create a business. Someone's understanding about entrepreneurial intention can be reflected as a tendency to practically build a business as suggested by Jenkins \& Johnson (1997).

The conceptual framework can be illustrated in figure 1, as follows:

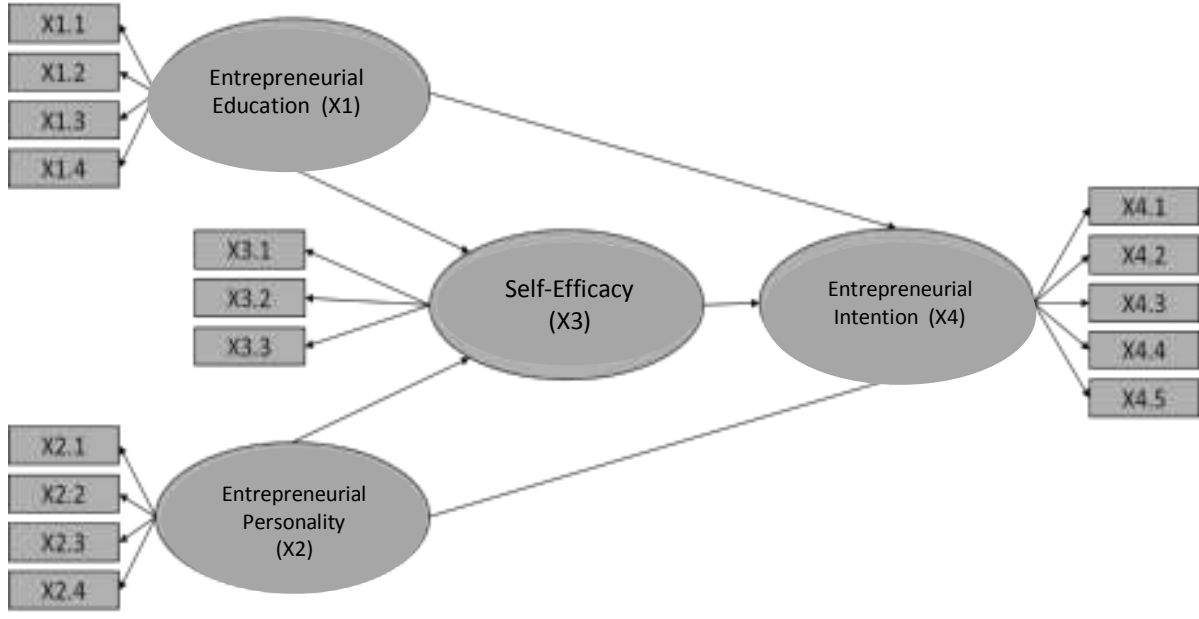

Figure 1. Conceptual Framework 


\section{RESEARCH HYPOTHESIS}

The researcher constructs five hypotheses on this research. They are both direct hypothesis (partial) and hypothesis which is constructed from more than two variables (stimulant). The following hypotheses in this research are:

Education is one of factors affecting entrepreneurial intentions. Entrepreneurial education aims to improve awareness of this line of work through entrepreneurial knowledge.

H1a $=$ the effect of entrepreneurial education to entrepreneurial intention.

Hoa $=$ the absence of entrepreneurial education effect to entrepreneurial intention.

Since everybody has different and unique character, entrepreneurial personality can be defined as a character possessed by someone to differentiate himself with another person. It is very much related to entrepreneurial intention. University students who possessed it were expected to nurture intention to be entrepreneur.

$\mathbf{H} \mathbf{1} \mathbf{b}=$ the effect of entrepreneurial personality to entrepreneurial intention.

Hob $=$ the absence of entrepreneurial personality effect to entrepreneurial intention.

Self-efficacy is a person's competence to solve a problem by his own. Being entrepreneur must acquire that competence, because it can nurture responsibility towards every action in the business. Moreover, it can also affect the entrepreneurial intention. $\mathrm{H} 1 \mathrm{c}=$ the effect of self-efficacy to entrepreneurial intention.

Hoc $=$ the absence of self-efficacy effect to entrepreneurial intention.

H1d = the indirect effect of entrepreneurial education to entrepreneurial intention through self-efficacy.

Hod = the absence of indirect entrepreneurial education effect to entrepreneurial intention through self-efficacy.

H1e = the indirect effect of entrepreneurial personality to entrepreneurial intention through self-efficacy.

Hoe = the absence of indirect entrepreneurial personality effect to entrepreneurial intention through self-efficacy.

\section{METHODS}

\section{Research Design}

This study was quantitative research which used survey method to the research respondent. The variables used in this research were exogenous, self efficacy and endogenous. The exogenous variable was the entrepreneurial education. The selfefficacy variable was the entrepreneurial personality. Lastly, the endogenous variable 
was the entrepreneurial intention. The instrument used to collecting the data has been already validated before.

Table 1. Research Variable

\begin{tabular}{|c|c|c|}
\hline Research variable & Indicator & \\
\hline \multirow{4}{*}{$\begin{array}{l}\text { Entrepreneurial } \\
\text { Education } \\
\left(X_{1}\right)\end{array}$} & 1.know-what (entrepreneurial knowledge) & $\mathrm{X} 1.1$ \\
\hline & 2.know-why (values and motives) & $\mathrm{X} 1.2$ \\
\hline & 3.know-who (social interaction) & $\mathrm{X} 1.3$ \\
\hline & 4.know-how (entrepreneurial skills and abilities) & $\mathrm{X}_{1.4}$ \\
\hline \multirow{4}{*}{$\begin{array}{l}\text { Entrepreneurial } \\
\text { Personality } \\
\left(\mathrm{X}_{2}\right)\end{array}$} & 1.need for achievement & $\mathrm{X} 2.1$ \\
\hline & 2. locus of control & $\mathrm{X} 2.2$ \\
\hline & (Sesen, 2012) & $\mathrm{X} 2.3$ \\
\hline & & $\mathrm{X} 2.4$ \\
\hline \multirow[t]{3}{*}{ Self-efficacy $\left(X_{3}\right)$} & 1. Assertive in thinking about how to achieve goal & $X_{3.1}$ \\
\hline & 2. Confidence in designing action & $x_{3.2}$ \\
\hline & $\begin{array}{l}\text { 3. Capable of self-motivation } \\
\text { (Indarti, 2008) }\end{array}$ & $x_{3.3}$ \\
\hline \multirow{5}{*}{$\begin{array}{l}\text { Entrepreneurial } \\
\text { intention } \\
\left(\mathrm{X}_{4}\right)\end{array}$} & 1. developing character to create a business & $\mathrm{X} 4.1$ \\
\hline & 2. choosing carrier as entrepreneur & $\mathrm{X} 4.2$ \\
\hline & 3. collaboration to start & $\mathrm{X} 4.3$ \\
\hline & 4. seeking opportunity & $\mathrm{X} 4.4$ \\
\hline & $\begin{array}{l}\text { 5.expand the networking with other entrepreneurs (Linan, } \\
2008 \text { ) }\end{array}$ & $\mathrm{X} 4.5$ \\
\hline
\end{tabular}

\section{Population}

The population of this research was 181 respondents of Nusantara PGRI University, Kediri. Precisely, they were students of Teacher Training and Education Faculty who received entrepreneurial course in their class.

\section{Sampling, Procedure, and Sample}

The samples used were 151 students who learn entrepreneurship in their class. The data collecting were done using closed questioner with liker scale (strongly disagree $=1$, disagree $=2$, neutral $=3$, agree $=4$, strongly agree $=5$ ). . The data collected were analyzed using Structure Equation Modeling (SEM) namely SmartPLS 3.0.

\section{RESEARCH FINDING AND DISCUSSION}

\section{The Research Instrument Testing}

The research instrument was previously tested to 30 students of Nusantara PGRI University who take entrepreneurship course. Based on the questionnaire used, the whole research instrument was valid and reliable. It was also proofed by Loading Factor of which the score were more than 0.7 and Cronbach's alpa more than 0.7 (Hariyono, 2017). The testing used SEM-PLS of which the validity is illustrated on Picture 2 . In other hand, the reliability is illustrated on figure 2 . 


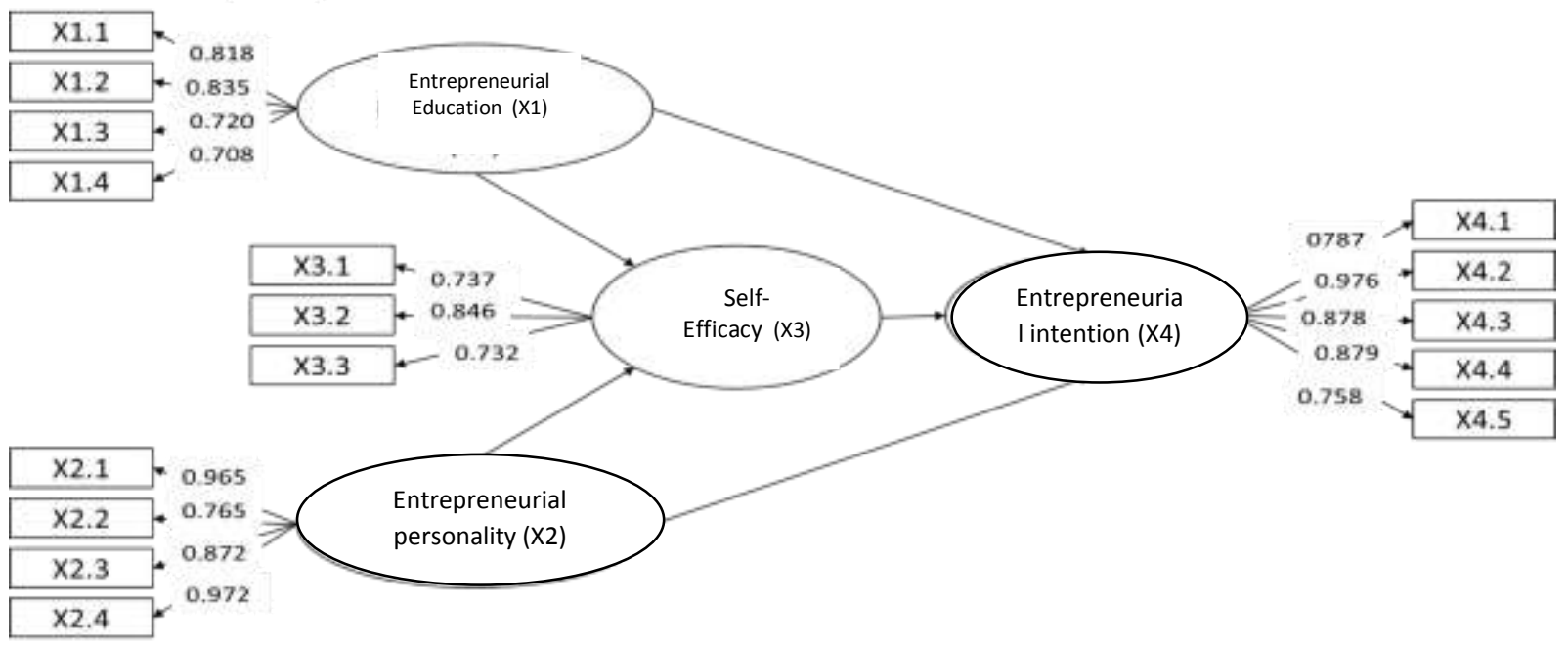

Figure 2. The Validity Test Result.

Table 2. The Reliability Test Result.

\begin{tabular}{ccc}
\hline Construct & Cronbach's Alpha & Description \\
\hline X1 & 0.776 & Reliable \\
X2 & 0.967 & Reliable \\
X3 & 0.867 & Reliable \\
X4 & 0.856 & Reliable \\
\hline
\end{tabular}

\section{The Construct Validity Testing}

The questionnaire used was valid because its Loading Factor score is 0.7 (Haryono, 2017). The Picture 3 is the result of data analyzing using SmartPLS 3.0.

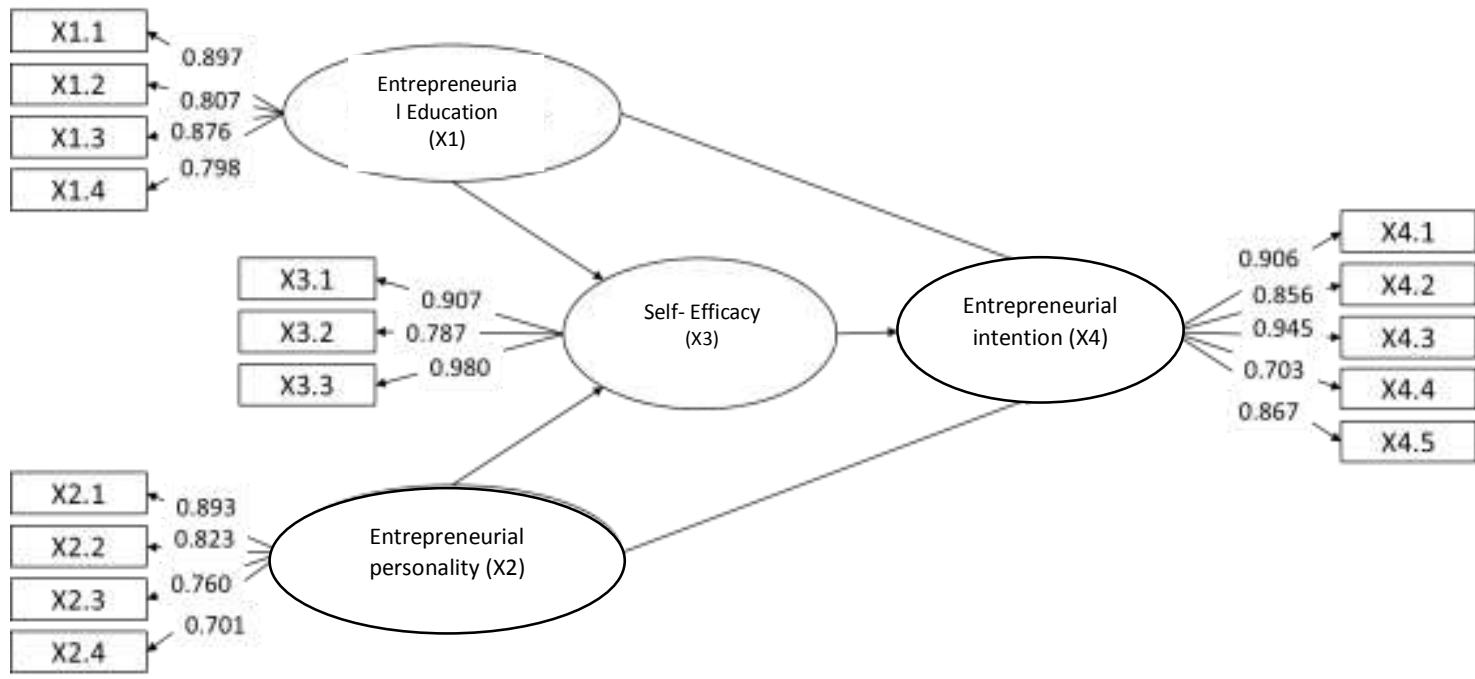

Figure 3. The Algorithm Result. 
The algorithm result on picture 2 shows that LF result of every instrument to its variable scores more than 0,7 . In other words, the instrument is valid so it can be used as research instrument.

\section{The Reliability Testing}

The latent variable will be reliable if the Cronbach's alpa and Composite Reliability scores more than 0.7 (Haryono, 2017). In contrast, if the Cronbach's alpa and Composite Reliability scores less than 0.7 , then it will be reliable. The following table is result of reliability test.

Table 3. Reliability Test Result

\begin{tabular}{cccc}
\hline Construct & Cronbach's Alpha & Composite Reliability & Description \\
\hline X1 $_{1}$ & 0.733 & 0.876 & Reliable \\
X2 $_{2}$ & 0.877 & 0.721 & Reliable \\
X3 $_{3}$ & 0.700 & 0.867 & Reliable \\
X $_{4}$ & 0.981 & 0.985 & Reliable \\
\hline
\end{tabular}

The table 3 shows that Cronbach's Alpha and Composite reliability X1 scores 0.733 and 0.876; Cronbach's Alpha and Composite reliability X2 scores 0.877 and 0.721; Cronbach's Alpha and Composite reliability $X_{3}$ scores 0.700 and 0.867 ; Cronbach's Alpha and Composite reliability $\mathrm{X}_{4}$ scores 0.981 and 0.985 . Those scores show that the whole variables were reliable. Table 4 shows the analysis from Output Cross Loading, as follows:

Table 4. The Result of Output Cross Loading Construct

\begin{tabular}{lllll}
\hline Code & X1 & X2 & X3 & X4 \\
\hline X1.1 & 0.774 & 0.403 & 0.477 & 0.294 \\
X1.2 & 0.615 & 0.391 & 0.284 & 0.276 \\
X1.3 & 0.818 & 0.524 & 0.540 & 0.373 \\
X1.4 & 0.771 & 0.393 & 0.477 & 0.285 \\
X2.1 & 0.609 & 0.775 & 0.278 & 0.257 \\
X2.2 & 0.508 & 0.880 & 0.512 & 0.372 \\
X2.3 & 0.516 & 0.804 & 0.545 & 0.462 \\
X2.4 & 0.459 & 0.817 & 0.375 & 0.299 \\
X3.1 & 0.509 & 0.621 & 0.757 & 0.278 \\
X3.2 & 0.499 & 0.502 & 0.741 & 0.455 \\
X3.3 & 0.428 & 0.605 & 0.844 & 0.321 \\
X4.1 & 0.489 & 0.822 & 0.344 & 0.884 \\
X4.2 & 0.484 & 0.431 & 0.748 & 0.873 \\
X4.3 & 0.341 & 0.280 & 0.702 & 0.772 \\
X4.4 & 0.465 & 0.454 & 0.796 & 0.848 \\
X4.5 & 0.422 & 0.282 & 0.719 & 0.767 \\
\hline
\end{tabular}

In relation to Table 4, the research variables scores the biggest output cross loading to its questionnaire. In other words, the questionnaire is applicable to the research variable. 


\section{Structural Model Evaluation (Inner Model)}

The Structural Model Evaluation (SEM) with PLS was done by R-Square (R2). Meanwhile significance test was done through coefficient estimation stripe. The following table shows the result of $R^{2}$ :

Table 5. Calculation Output of $\mathrm{R}^{2}$

\begin{tabular}{cc}
\hline Variable & Score $^{2}$ \\
\hline Self-efficacy (X3) & 0.668 \\
Entrepreneurial Intentions (X4) & 0.756 \\
\hline
\end{tabular}

$R^{2}$ score was used to measure the effect of exogenous latent variable to endogenous latent variable. The both result of $\mathrm{R}^{2}$ on latent endogen variable were 0.668 and the 0.756. It shows that the model was the reliable one.

\section{Significance Test}

The significance test on SEM PLS model is done to identify the effect of exogenous latent variable to endogenous latent variable. The hypothesis evaluation on SEM can be observed from Bootsrapping analysis result using SmartPLS 3.0. The analysis result is illustrated on picture 4 , as follow:

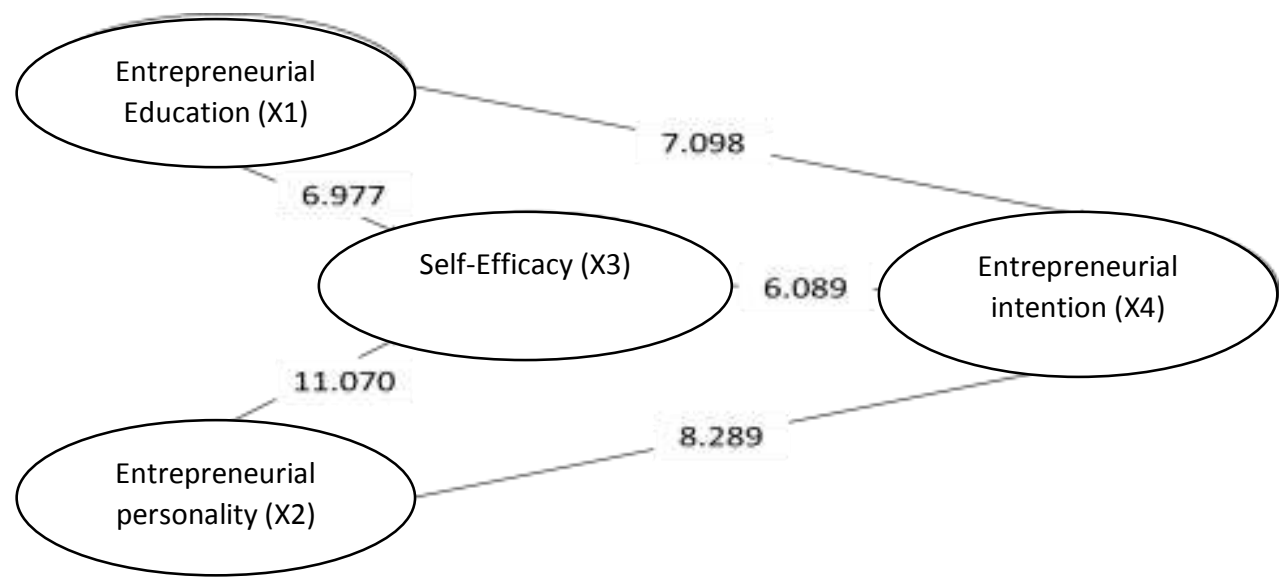

Figure 4. Boostrapping Result

Before testing the hypothesis which was constructed previously, it was identified that the table used was 1.96 (Haryono,2017). The following are the result of hypothesis testing:

$\mathbf{H} \mathbf{a}^{\mathrm{a}}=$ the effect of entrepreneurial education $\left(\mathrm{X}_{1}\right)$ to the entrepreneurial intention $\left(\mathrm{X}_{4}\right)$

$\mathbf{H O}^{\mathrm{a}}=$ the absence of entrepreneurial education effect $\left(\mathrm{X}_{1}\right)$ to the entrepreneurial intention (X4)

The result of Boostrapping output shows the t statistic of entrepreneurial education's effect variable (X1) to the entrepreneurial intention $\left(X_{4}\right)$ is 7.098. It is bigger than 1.96. As a result, the entrepreneurial education affects $\left(X_{1}\right)$ the entrepreneurial intention $\left(X_{4}\right)$. 
$\mathbf{H}_{1}{ }^{\mathbf{b}}=$ the effect of entrepreneurial personality $\left(X_{2}\right)$ to the entrepreneurial intention $\left(X_{4}\right)$

$\mathbf{H o}^{\mathrm{b}}=$ the absence of entrepreneurial education effect $\left(X_{2}\right)$ to the entrepreneurial intention (X4)

The result of Boostrapping output shows the $t$ statistic of entrepreneurial personality's effect variable $\left(X_{2}\right)$ to the entrepreneurial intention $\left(X_{4}\right)$ is 8.289 . It is bigger than 1.96. As the conclusion, the entrepreneurial personality $\left(X_{2}\right)$ affects the entrepreneurial intention $\left(\mathrm{X}_{4}\right)$.

$\mathbf{H}^{\mathbf{c}}=$ the effect of self-efficacy $\left(X_{3}\right)$ to entrepreneurial intention $\left(X_{4}\right)$

$\mathbf{H o}^{c}=$ the absence of self efficacy effect to entrepreneurial intention

The result of Boostrapping output shows the t statistic of self-efficacy's effect variable $\left(X_{3}\right)$ to entrepreneurial $\left(X_{4}\right)$ is 6.089. It is also bigger than 1.96. Therefore, self-efficacy $\left(X_{3}\right)$ affects the entrepreneurial intention $\left(X_{4}\right)$.

$\mathbf{H}^{\mathbf{d}}=$ the indirect effect of entrepreneurial education to entrepreneurial intention through self efficacy

$\mathbf{H o}^{\mathrm{d}}=$ the absence of entrepreneurial education indirect effect to entrepreneurial intention through self efficacy

Entrepreneurial education directly affects entrepreneurial intention. In the same way, self-efficacy directly affects entrepreneurial intention. Based on those finding, it can be concluded that entrepreneurial education indirectly affects to entrepreneurial intention through self-efficacy.

$\mathrm{H}_{\mathbf{1}}{ }^{\mathrm{e}}=$ the indirect effect of entrepreneurial education to entrepreneurial intention through self-efficacy

$\mathrm{Ho}^{\mathrm{e}}=$ the absence of entrepreneurial education indirect effect to entrepreneurial intention through self-efficacy

Entrepreneurial personality directly affects entrepreneurial intention. Similarly, selfefficacy directly affects entrepreneurial intentions. It can be concluded that entrepreneurial personality to entrepreneurial intention through self-efficacy.

\section{DISCUSSION}

Based on the findings, the entrepreneurial education affects entrepreneurial intention. The $t$ statistic score of it is 7.098 which is bigger than 1.96. The findings are in line with Athayde research (2009) which finds that entrepreneurial education affect entrepreneurial intention. The students of Nusantara PGRI University are in strategic age to start a business. At least, they have intention to be entrepreneur. The high entrepreneurial intention on students will giving birth an independence young entrepreneur who has great responsibility toward his business. The entrepreneurial education is expected to nurture intention to start business. Experiences and knowledge from that education are expected to raise desire to be young entrepreneur.

Entrepreneurial personality affects entrepreneurial intention of which the $t$ statistic scores 8.289 that is bigger than 1.96. The result shows that entrepreneurial personality affects the entrepreneurial intention. A person who come up with entrepreneurial intention surely possesses desire to be successful in his business (Linan, 2011). Unlike, those who don't have faith to be entrepreneur, having entrepreneurship experience may drive someone to act and pursue himself on becoming successful businessman.

252 Management and Economics Journal (MEC-J)

Vol 3 (3) December 2019 
That research is supported by the latest research about the effects of entrepreneurial personality towards entrepreneurial intention (Sesen, 2013).

Self efficacy affects entrepreneurial intention of which the $t$ statistic scores 6.089 that bigger than 1.96. Self-Efficacy will make a person responsibly complete task or job he starts. Similarly, on having entrepreneurial intention, a person needs self-efficacy. Selfefficacy is self-transformation process, evaluation and self choice to manipulate action while doing business. It is in line, with research conduct by Oktaviana \& Umami (2018); Nurhidayah \& Purwanto (2014).

Based on the first, second, and third hypothesis partially can be concluded that through self-efficacy there are indirect effect of entrepreneurial education towards entrepreneurial intention. On the other hand, through self-efficacy entrepreneurial personality also indirectly affects the entrepreneurial intention. Entrepreneurial education and personality are the variable which affects Nusantara PGRI university students' entrepreneurial intention. In addition, those also can affect entrepreneurial intention through self-efficacy. The higher entrepreneurial education, personality and self-efficacy possessed by students of Nusantara PGRI University Kediri, the more it will nurture their entrepreneurial intention. As a result, it were hoped that the whole Nusantara PGRI University Kediri circles could improves entrepreneurial education, personality and self efficacy through many ways.

\section{CONCLUSION}

Based on the findings from the research above, there are five point concluded as follows: (1) entrepreneurial education affects to entrepreneurial intention, (2) entrepreneurial personality affects to entrepreneurial intention, (3) self-efficacy affects to entrepreneurial intention, (4) entrepreneurial education indirectly affects entrepreneurial intention through self-efficacy, and (5) entrepreneurial personality indirectly affects entrepreneurial intention through self-efficacy. The five hypotheses are proven having positive effects. This research is also supported by the previous research conducted on the same topic.

\section{REFERENCES}

Alma, B. (2011). Kewirausahaan untuk Mahasiswa dan Umum. Bandung: CV Alfabeta.

Anoraga, P. (2003). Psikologi Kepemimpinan. Jakarta: Rineka Cipta.

Athayde, R. (2009). Measuring Enterprise Potential in Young People Entrepreneurship: Theory \& Practice. 33(2), 481-500

Bandura. (1977). Social Learning Theory. New York: General Learning Press.

Cruz, N.M., Escudero, A.R., Barahona, J.H \& Leitao, F.S. (2009). The Effect Entrepreneurship Education Programmes on Satisfaction With Innovation Behavior and Performance. Journal of European Industrial Training. 33(3), 198-214

Dorland, WAN. (2002). Kamus Kedokteran Dorland. Edisi 29. Jakarta: ECG

Hermawan, K. (2003). Marketing In Venus. Jakarta: Gramedia Pustaka Utama 
Indarti, N \& Langerberg, M. (2004). Factor Affecting Business Success Among SMEs : Empirical Evidences from Indonesia. The Netherland :Proceedings of The Second Bi-Annual European Summer University. 19(20)

Indarti, R. (2008). Intensi Kewirausahaan Mahasiswa: (Studi Perbandingan Antara Indonesia, Jepang dan Norwegia. Jurnal Ekonomika dan Bisnis Indonesia, 23 (4). 2-26

Izedonmi, P \& Okafor, C. (2010). The Effect Of Entrepreneurship Education On Students' Entrepreneurial Intention. Global Journal of Management and Business Research. 10 (6)

Jenkins, M \& Johnson, G. (1997). Entrepreneurial Intentions and Outcomes: A Comparative Causal Mapping Study. Journal Management Studies, 34,895-920

Kristiansen, S \& Indarti, N. (2004). Entrepreneurial Intention among Indonesian and Norwegian Students. Journal of Enterprising Culture, 12 (1), 55-78

Lee, S.H \& Wong, P.K. (2004). An Exploratory Study of Technopreneurial Intention: A Career Anchor Perpective. Journal of Business Venturing, 19(1): 7-28

Linan, F. (2008). Skill And Value Perceptions: How Do They Affect Entrepreneurial Intentions. International Entrepreneur Management Journal, 4, pp. 257-272.

Saroni, M. (2012). Mendidik \& Melatih Entrepreneur Muda. Yogyakarta: Ar- Ruzz Media

Sesen, H. (2013). Personality or Enviroment? A Comprehensive Study on The Entrepreneurial Intentions of University Students. Turkey: Emerald Insight Journal. 55(7), 625-639

Subijanto. (2012). Analisis Pendidikan Kewirausahaan di Sekolah Menengah Kejuruan. Jurnal Pendidikan dan Kebudayaan, 18 (2), 163-173

Tung, L. C. (2011). The Impact Of Entrepreneurship Education On Entrepreneurial Intention Of Engineering Students. City University of Hongkong: Run Run Shaw Library

Wibowo, A. (2011). Pendidikan Kewirausahaan (Konsep dan Strategi). Yogyakarta: Pustaka Pelajar

Haryono, S. (2017). Metode SEM untuk Penelitian Manajemen AMOS LISREL PLS. Jakarta Timur: Luxima Metro Media.

Nurhidayah \& Purwanto (2014) Pengaruh Efikasi Diri Terhadap Intensi Berwirausaha Mahasiswa Program Studi Pendidikan Administrasi Perkantoran Angkatan 20102012 FE UNY. Jurnal online.

https://www.academia.edu/10660500/Pengaruh_Efikasi_Diri_terhadap_Intensi_Berwir auraha_Mahasiswa_Prodi_Pendidikan_Administrasi_Perkantoran_UNY?auto=downloa d)

Oktaviana, V. D. \& Umami, N. (2018). Pengaruh efikasi diri dan kreativitas terhadap intensi berwirausaha pada siswa kelas xi smk negeri pogalan tahun ajaran 2017/2018. Jurnal Pendidikan Ekonom, 11(2) 